International Journal of Applied Linguistics \& English Literature

ISSN 2200-3592 (Print), ISSN 2200-3452 (Online)

Vol. 1 No. 5; September 2012 [Special Issue on General Linguistics]

\title{
Perceptual Convergence as an Index of the Intelligibility and Acceptability of Three Nigerian English Accents
}

\author{
Fatimayin Foluke (Ph.D) \\ National Open University Of Nigeria, Lagos. Nigeria \\ Tel: $2348033773268 \quad$ E-mail: folukefatimehin@yahoo.com.
}

Received: 27-05- 2012

Accepted: 26-07- 2012

Published: 03-09- 2012

doi:10.7575/ijalel.v.1n.5p.100

URL: http://dx.doi.org/10.7575/ijalel.v.1n.5p.100

\begin{abstract}
This study investigated perceptual convergence as a measure of the intelligibility and acceptability of three Nigerian English (NE) accents with a view to arriving at a possible norm of usage for teaching and communication purposes. The subjects were one hundred and eighty Nigerians of varied socio-economic, educational and ethno-linguistic backgrounds drawn from various offices, institutions in Kaduna, Enugu, Ibadan. Two researcher-designed instruments were used. First is the Oral Reading Test for Accent identification made up of phonological difficulties usually exhibited by NE language users. Next is a questionnaire in the form of an intelligibility and acceptability rating scale. Based on the findings, the educated NE accent was the most intelligible and acceptable, followed by the mother-tongue based NE accent and the Regional NE accents. It was recommended among others that language policy makers confront the problem of the NE corpus to be used in teaching and the Nigerian Educational Research and Development Council be commissioned to produce texts on the phonology and phonetics of the Educated NE accent.
\end{abstract}

Keywords: Perceptual convergence, index, Nigerian English, Accents, Intelligibility, Acceptability

\section{Introduction}

The language situation in Nigeria is a result of languages in contact. This paved the way for the evolution of bilingualism / multilingualism.. However, languages can hardly come in contact without cultures coming together. The coming together of different cultures and languages aided the evolution of Nigerian English (NE). The evolution of NE emphasizes the fact that the appropriate use of the English language (EL) in Nigeria must reflect the society as well as serve her citizens and not overwhelm them. Jowitt (1991) observed that sympathetic 'sorry' is the conventional translation of a one word lexeme in the mother tongues (MTs). For example, Hausa, 'sannu,' Igbo 'ndo', Yoruba: 'pele', Tiv: 'nsugh', Edo: 'koyo', etc. These are local words for 'sorry' in EL. This and others are peculiarly Nigerian and cannot be said to break general rules. They are rather justified on semantic grounds showing an adaptation of the vocabulary of the EL to fill a semantic gap that exists because of the difference between British and Nigerian cultures/languages. This too could be justifiable for NE accents. That is, accents to be used by Nigerians should be Nigerian so as to fill the phonological gaps that exist because of differences between British and Nigerian phonological set ups and articulatory settings.

Another problem which NE would hopefully be a cure for is in language teaching and testing. The continued dominance of the EL and the ambiguous language policy are mostly at the root of the teaching and learning problems. This is compounded by the projection of standard British English (SBE) as being superior to all varieties of English in Nigeria. According to Odumuh cited in Ohia (1997), one of the problems of teaching English in Nigeria is in the confusion as to what to accept as permissible regional varieties and what to reject as 'sub-standard'.

An acceptable Nigerian variety of the EL would be of help in finding a lasting solution to the above problem. This is necessary at this point because the issue of the increasing functions of the EL as the language of instruction, commerce, law, etc., without a change in status as second language $\left(\mathrm{L}_{2}\right)$ has a direct relationship with students' poor performance in public examinations. The immediate concern should be to develop a norm that would be generally acceptable as standard Nigerian spoken English. This may upon approval be taken as a basis for assessing language competence in the educational system as well as for communication purposes. Efforts should be geared towards integrating the EL and the indigenous languages for effective communication and as a solution 
International Journal of Applied Linguistics \& English Literature

ISSN 2200-3592 (Print), ISSN 2200-3452 (Online)

Vol. 1 No. 5; September 2012 [Special Issue on General Linguistics]

to the country's language problems. This is really necessary as attempts at promoting the indigenous languages through the language in education policy (National Policy on Education, revised draft 2007) have not been fruitful. The most likely option now as a forward is an acceptable variety of NE. This is premised on the fact that since the local languages are not used in schools as stipulated in the policy, using and adopting a homegrown Nigerian variety of the EL is likely to be more intelligible and acceptable to users and may be a means of achieving objectives of teaching/learning.

\subsection{Background literature on Nigerian English (NE)}

The emergence of NE is no longer in doubt. Odumuh (1984) asserted that NE has emerged and stabilized. It is a term used in reference to the variety of English used in Nigeria which is neither pidgin nor Standard British. It is English with a distinctive Nigerian flavour, resulting from contact between the EL and Nigerian languages. It is an indigenized variety of English as an international language. Therefore the evolution of NE can be associated with the strive to achieve a linguistic identity.

The development of NE followed the global patterns described as the result of contact between languages and cultures. Describing the development and inevitability of NE, Soyinka (1993), submitted that English was forced to play "unaccustomed roles" which turned it into 'a new medium of communication in a new organic series of mores, social goals, relationships, all of which go into the creation of a new culture' and by extension a new variety of the language i.e. NE. While it is true that NE has emerged and has distinct linguistic features, it is also true that it has not fully developed into a standard comparable to other world standard Englishes. This is because there are still some fundamental issues to be resolved. But out of the varieties that exist, a norm can be identified as being intelligible and acceptable by all for the linguistic purpose of the Nigerian nation. This will in turn enable the Nigerian variety assume the role of a national language as well as contribute to the varieties of World Standard Englishes (WSE: Kachru, 1992).

World Englishes refers to the emergence of indigenized varieties of the English language. It consists of varieties of English used in diverse sociolinguistic contexts globally. It is an outcome of how sociolinguistic histories, other cultures and languages influence the use of English in different climes where it was transported. Crystal (2007) asserts that establishing the total number of Englishes around the world is difficult as new varieties of English are constantly being developed and discovered. The English language has enjoyed tremendous linguistic patronage in the last 300 years. This according to Kachru (1992) is because of its range and depth. Factors that aided the global spread of English are economic, political, scientific and technological. While economic considerations aided its spread across the globe, political considerations helped in stabilizing such influences. Official policies also helped. These are the introduction of the American Peace Corps program, and the posting of American and British military personnel to different parts of the world. These helped in the spread of the English language. In addition, the official language policy which promoted the B.B.C. and V.O.A. as means of information dissemination and sometimes propaganda aided the spread. Political associations like the E.U., the Commonwealth have helped stabilize the use of English. The advancement of science and technology has also helped. This is because scientific breakthroughs recorded in the West as well as numerous technological feats have been documented in the language. Therefore a world that is becoming dependent on technology has come to rely on the use of the English language (Awonusi, 2004).

An inevitable consequence of this global spread is that the language will become open to the winds of linguistic change in totally unpredictable ways. This has already happened as evidenced in the emergence of new varieties of English in the different territories where the language has taken root. These new Englishes are somewhat like dialects we all recognize within our own country except that they are on an international scale applying to whole countries or regions. They are the inevitable consequence of the spread of the English language on a global scale.

Speaking on new, national and international Englishes in an attempt to portray the rapid growth of the English Language, Kachru (1992) divided its speakers into three. The 'inner circle' is made up of native English speaking countries such as the U.K., U.S.A., Canada, Australia, and New Zealand. The 'outer circle' consists of countries in the African territories, the Indian sub-continent, and the Pacific. These are countries like Nigeria, Ghana, Kenya, India, Pakistan; Singapore, etc. English here co-exists with many indigenous languages and functions as L2. In these countries, there exist several nativized varieties of the English language. The 'expanding circle' of Kachru's division is made up of countries in the far East (China, Indonesia, Japan, Taiwan, etc), Middle East (Israel, Egypt, S. Arabia), and Zimbabwe where English is a foreign language. (See fig. 1). 
Countries using English

as Further Tongue (e.g.

countries of the arabophone,

Francophone and lusophone

world such as Tunisia, Togo,

Mexico, etc.

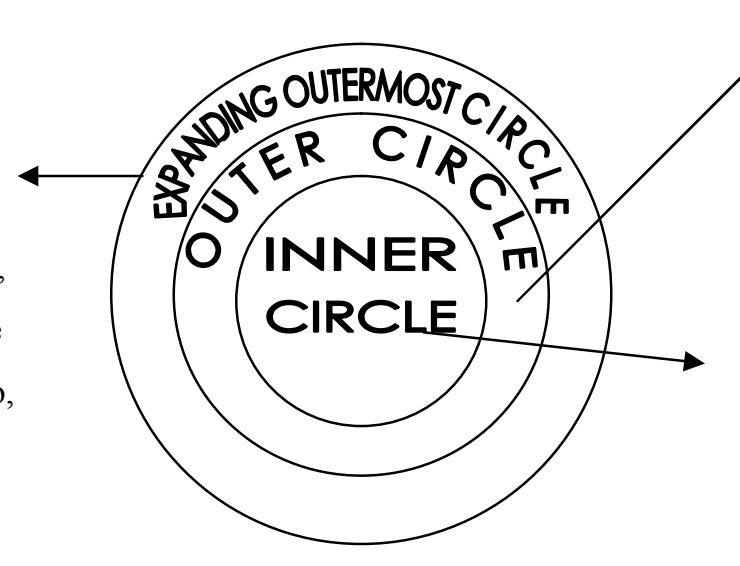

Countries using English as

Other Tongue (i.e. the Anglophone world e.g. Nigeria, Ghana, the Philippines)

Countries using English as Mother Tongue (e.g. England, USA and Australia

FIG.1. Lawal's (2006) Slightly Modified Version of Kachru's (1992) Trichotomy Showing L1, L2 And F1 Users Of English

Kachru's inner circle is of native English speaking countries. These are 'norm providing, his 'outer-circle' consist of ESL countries and are 'norm-developing, while his 'expanding-circle' comprises EFL countries. These are 'norm-dependent' in the sense that the criteria for judging usage are imported from U.K and U.S.A.

NE has many varieties. Empirical work in the area of the phonology of NE can be examined in two parts. The first relates to research on varieties differentiation. Brosnaham (1958) suggested a typology of four varieties based on educational attainment. Banjo (1979) identified four varieties based on linguistic deviations from the standard. Another typology is the regional parameter separating Hausa English (northern) from Igbo English (eastern) from Yoruba English (western). The second part of the empirical research on the phonology of NE relates to tests of intelligibility and acceptability. These include Tiffen's (1974) study, Ekong (1980), Jibril (1986). The findings suggest that while social acceptability is subject to the democratic process, international intelligibility is more elite inclined (Banjo, 1979). However, Adetugbo (1987) argued that international intelligibility is an unnecessary luxury. To him, there is no reason for this especially as Americans, Australians, Scots have their own varieties of the EL and nobody bothers about international intelligibility especially as these are mutually intelligible regional varieties.

In support of the above, it is the opinion of this writer that language should serve users by enabling them use it to express their own identity as well as relate with others around them. It should also be a reflection of their total culture. Based on this, what is needed is national intelligibility and acceptability as a first step in the right direction for Nigerian spoken English.

\subsubsection{Statement of the Problem}

After almost two centuries of its advent in the country, EL usage is characterized by some Nigerians using SBE, others, educated Nigerian spoken English and for a large majority, MT interference is common. This is a result of the English language being badly taught. In addition, the influence of the native languages has made performance in the EL peculiar.

The focus of this study is on the intelligibility and acceptability of NE accents in relation to the perception and metaperception of the users with a view to identifying the convergence of agreement. The convergence can serve as a pointer towards the norm and also determine the reference point for standardization. It therefore used the degree of convergence among the users' perception, other accents users' perception and users' metaperception to measure the intelligibility and acceptability of NE accents. Self perception is how the user of an accent perceives the accent, other users' perception is how other users perceive an accent not their own, and metaperception is the perception of the user of an accent about how other users perceive her/his accent. The convergence point is the point of overlap among the three perceptual types relative to each of the three NE accents. 


\subsubsection{Purpose of the Study}

The purpose of the study is to find out whether perceptual convergence can be used as a measure of the intelligibility and acceptability of three NE accents.

\subsubsection{Research Questions}

The following questions were addressed in the study:

1. What is the users' self perception, other users' perception and user's metaperception of the intelligibility of each of NE accent 1 (i.e. ENEA), NE accent 2 (RNEA), NE accent 3 (MTBNEA).

2. What is the users' self perception, other users' perception and user's metaperception of the acceptability of each of NE accent 1 (i.e. ENEA), NE accent 2 (RNEA), NE accent 3 (MTBNEA)?

\subsubsection{Research Hypotheses}

The following hypotheses were formulated as a guide to the study.

$\mathbf{H o}_{1}$ : There is no significant difference in the users' perception, other accents users' perception and the users' metaperception of the intelligibility of Accent 1 (i.e. ENEA)

$\mathbf{H o}_{2}$ : There is no significant difference in the users' perception, other accents users' perception and the users' metaperception of the intelligibility of the Accent 2(i.e. RNEA)

$\mathrm{Ho}_{3}$ : There is no significant difference in the user' perception, other accents users' perception and the users' metaperception of the intelligibility of accent 3 (MTBNEA)

Ho$_{4}$ : There is no significant difference in the user' perception, other accents users' perception and the users' metaperception of the acceptability of accent 1 (ENEA)

Ho $_{5}$ : There is no significant difference in the user' perception, other accents users' perception and the users' metaperception of the acceptability of accent 2 (RNEA)

Ho $_{6}$ : There is no significant difference in the user' perception, other accents users' perception and the users' metaperception of the acceptability of accent 3(MTBNA)

\subsubsection{Conceptual Framework}

This study is conceptualized around some sociolinguistic, psycholinguistic and linguistic issues and concepts. The theory of languages in contact is of importance to these concepts and issues, that is the evolution of a new speech form from the communion of two or more languages. Closely related to the contact theory is the concept of varieties. The varieties of English are a result of languages in contact. They can also be regarded as the production of psycholinguistic interaction between two or more linguistic systems, those of the mother tongues (MTs) and the second language (L2). Also important is the social contact arising from the interaction between members of these groups which results in cultural and linguistic diffusion producing different varieties. These varieties are of interest in this study.

Crucial to the understanding of these varieties and the present study is the term accent. The Nigerian user of the English language learns it as a second language long after his first language mainly through formal instruction in school. In addition, the phonological and articulatory settings of the first and second languages are different. These

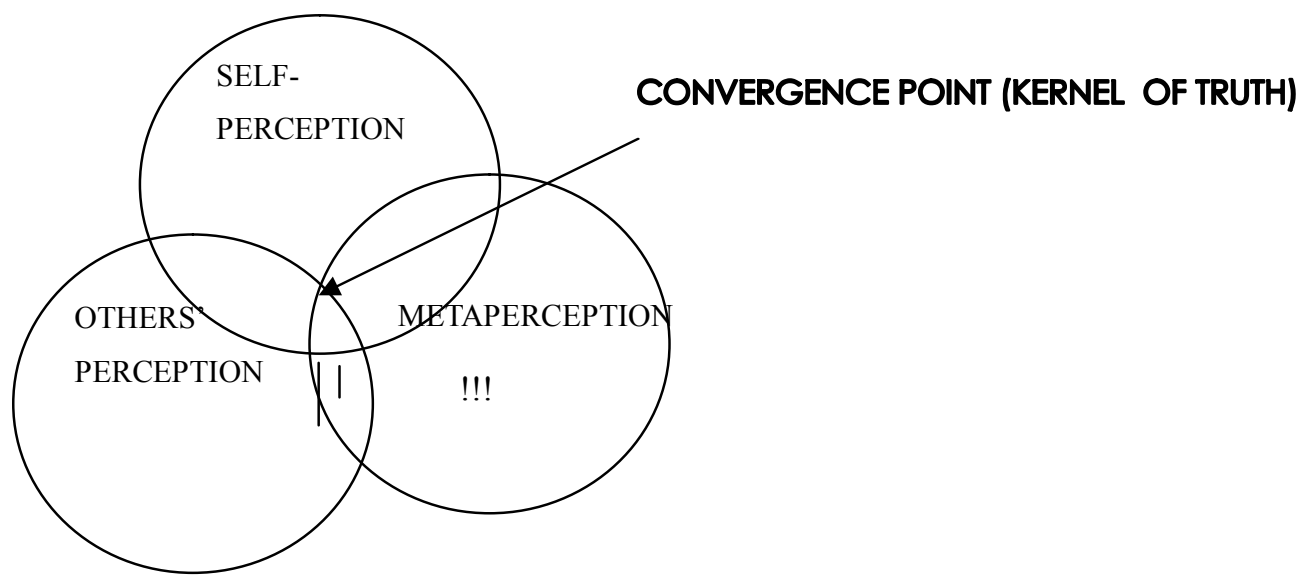

Fig 2.Adapted from Lawal (2000). Assessing Acceptability/Intelligibility of NE Accents. 
International Journal of Applied Linguistics \& English Literature

ISSN 2200-3592 (Print), ISSN 2200-3452 (Online)

Vol. 1 No. 5; September 2012 [Special Issue on General Linguistics]

result in NE accents different from the SBE accents. How intelligible and acceptable these NE accents would be to Nigerian EL users is of interest to this study. Since NE is a product of this complex sociolinguistic environment, it is obvious that its growth, understanding and acceptability will depend on the perception of those in the society. Perception and metaperception are very crucial to language understanding especially in L2 situation. This is because all language understanding begins with perception. Jowitt (1991) posits that in language understanding, perception precedes production and cognition precedes perception. Related to this is the need to know how others perceive us. Knowing how others perceive us is an important aspect of one's social life. It will enable individuals to understand their language use as well as that of others. It follows then that users' self perception of their own accent, other accents users' perception and user's metaperception would be an indicator of which accent is generally intelligible and acceptable. This is illustrated in figure 2.

\section{Methodology}

This is a descriptive survey type. The population for this study comprised all Nigerian users of the EL. The target populations are Nigerians with varying levels of formal education: graduates, Nigerian Certificate in Education holder (NCE), undergraduates, primary school graduates, newscasters, professionals etc. The country was divided into three language regions i.e. North (Kaduna, Hausa dominated), East (Enugu, Igbo dominated), West (Ibadan, Yoruba dominated), using stratified sampling. Incidental sampling was used to get the organizations and establishments where the samples were reached. Random sampling was carried out to get the required number of 60 respondents per region. The distribution of the sample is represented in the table.

Table1. Sampling Grid

\begin{tabular}{|l|l|l|l|l|}
\hline Regions & North & West & East & Total \\
\hline Accent & 20 & 20 & 20 & 60 \\
\hline 1 & 20 & 20 & 20 & 60 \\
\hline 2 & 20 & 20 & 20 & 60 \\
\hline 3 & 60 & 60 & 60 & 180 \\
\hline Total & & & & \\
\hline
\end{tabular}

Two researcher-designed instruments were used. First is the Oral Reading Test for Accent Identification. Here, an admixture of NE users read a short passage and sentences. These not only have areas of phonological difficulties usually exhibited by NE language users but all the sound segments of the language. A table of specification of items on the test was used to streamline respondents into the appropriate accents used by them. Next, the intelligibility and acceptability rating scale in form of a questionnaire with speech recording of the accents used by three speakers, one from each of the identified language regions was used to obtain respondents' views. The questionnaire was drawn in such a way that respondents were also judges of how intelligible and acceptable the accents they listened to were.

The reliability index of the instruments was determined through test-retest technique three weeks after the first administration. Using Pearson Product Moment Correlation Statistics, a reliability coefficient of 0.72 was obtained. The writer personally monitored the speech recordings, listened to respondent read and administered the questionnaire. Data was analyzed using mean, and Standard Deviation (SD) to answer the research questions, while the six hypotheses were analyzed with the statistical tool of Analysis of Variance (ANOVA).

\subsection{Analysis of Results}

The analysis of data collected and the results of the investigation carried out are reported. The analysis is based on the research questions and hypotheses stated in the write up. The mean, SD, and Analysis of Variance (ANOVA) results are presented in tables followed by a summary of the findings.

Research Question 1: What was users' self-perception, other users' perception and user's metaperception of the intelligibility of each of the three NE accents? 
International Journal of Applied Linguistics \& English Literature

ISSN 2200-3592 (Print), ISSN 2200-3452 (Online)

Vol. 1 No. 5; September 2012 [Special Issue on General Linguistics]

Table 2. Mean and SD results of user's self perception, other users' perception and user's metaperception of the intelligibility of each of the three NE accents.

\begin{tabular}{|l|l|l|l|l|}
\hline & & $\begin{array}{l}\text { ENEA } \\
(\text { Accent1 }\end{array}$ & $\begin{array}{l}\text { RNEA } \\
(\text { Accent2) }\end{array}$ & $\begin{array}{l}\text { MTbNEA } \\
\text { (Accent3) }\end{array}$ \\
\hline \multirow{2}{*}{$\begin{array}{l}\text { User's self } \\
\text { perception }\end{array}$} & Mean & 2.54 & 2.46 & 2.71 \\
\cline { 2 - 5 } & SD & .986 & .943 & 1.02 \\
\hline $\begin{array}{l}\text { Other accent } \\
\text { users' } \\
\text { perception }\end{array}$ & Mean & 2.67 & 2.60 & 2.63 \\
\cline { 2 - 5 } & SD & .947 & .999 & .870 \\
\hline $\begin{array}{l}\text { User's } \\
\text { metaperception }\end{array}$ & Mean & 2.70 & 2.54 & 2.46 \\
\cline { 2 - 5 } & SD & .975 & .859 & .888 \\
\hline
\end{tabular}

Table 2 indicates that Accent 3 was the most intelligible, followed by accent 1 . Accent 2 was the least intelligible. This is based on respective user's self perception. The table also indicates that Accent 1 was the most intelligible, Accent 2 was intelligible and Accent 3 was the least intelligible according to respective users' metaperception of the accents.

Research Question 2: What was the user's self-perception, other users' perception and user's metaperception of the acceptability of each of the three NE accents?

Table 3. Mean and SD results of users'self-preception, other users' perception and user's metaperception of the acceptability of each of the three NE accents

\begin{tabular}{|l|l|l|l|l|}
\hline & & $\begin{array}{l}\text { ENEA } \\
\text { (Accent1 }\end{array}$ & $\begin{array}{l}\text { RNEA } \\
\text { (Accent2) }\end{array}$ & $\begin{array}{l}\text { MTbNEA } \\
\text { (Accent3) }\end{array}$ \\
\hline Users'self-perception & Mean & 2.84 & 2.68 & 2.48 \\
\cline { 2 - 5 } & SD & .917 & 1.02 & .944 \\
\hline $\begin{array}{l}\text { Other Users' } \\
\text { perception }\end{array}$ & Mean & 2.76 & 2.72 & 2.73 \\
\cline { 2 - 5 } & SD & .935 & .937 & .905 \\
\hline $\begin{array}{l}\text { User's } \\
\text { metaperception }\end{array}$ & Mean & 2.68 & 2.58 & 2.44 \\
\cline { 2 - 5 } & SD & .970 & 1.01 & .933 \\
\hline
\end{tabular}

Table 3 shows that Accent 1 was the most acceptable, Accent 2 was acceptable and Accent 3 was the least acceptable according to users' self-perception of the acceptability of the accents. The table also indicates that Accent 1 was the most acceptable and Accent 2 was the least acceptable according to other users' perception.

Overall, the table shows that Accent 1 was the most acceptable while accent 3 was the least acceptable according to users' meatperception.

\subsubsection{Hypotheses Testing}

Hypotheses 1: There is no significant difference in users' self-perception, other accents users' perception and users' metapercerption of the of the intelligibility of the intelligibility of Accent1.

Table 4. ANOVA result of each users' self-perception, other accents users' perception and users' 
International Journal of Applied Linguistics \& English Literature

ISSN 2200-3592 (Print), ISSN 2200-3452 (Online)

Vol. 1 No. 5; September 2012 [Special Issue on General Linguistics] metaperception of the intelligibility of Accent1

\begin{tabular}{|l|l|l|l|l|l|l|}
\hline & $\begin{array}{l}\text { Sum of } \\
\text { square }\end{array}$ & $\begin{array}{l}\text { Dean } \\
\text { squar } \\
\text { e }\end{array}$ & F & Sig & Decision \\
\hline $\begin{array}{l}\text { Between } \\
\text { groups }\end{array}$ & 19.83 & 2 & 9.91 & 2.98 & .050 & Significant \\
$\begin{array}{l}\text { Within groups } \\
\text { Total }\end{array}$ & 389.30 & 177 & 3.33 & & & \\
\hline
\end{tabular}

Duncan post hoc Test Result.

\begin{tabular}{|l|l|l|r|}
\hline Intelligibility of Accent & & $\begin{array}{l}\text { Subset for } \\
\text { alpha }=.05\end{array}$ & \\
\hline & $\mathrm{N}$ & $\mathrm{I}$ & \\
Users'self perception & 49 & 5.12 & $*_{\mathrm{a}}$ \\
Other accent User's perception & 58 & 5.29 & $\mathrm{a}$ \\
User's metaperception & 73 & 5.42 & $\mathrm{~b}$ \\
Significance & & .369 & \\
\hline
\end{tabular}

* Means of the same letter are not significantly different

Hypothesis 2: There is no significant difference in users' metaperception of the intelligibility of Accent 2.

Table 5. ANOVA result of each users' self-perception, other accents users' perception and users' metaperception of the intelligibility of Accent 2

\begin{tabular}{|l|l|l|l|l|l|}
\hline & $\begin{array}{l}\text { Sum of } \\
\text { squares }\end{array}$ & Df & $\begin{array}{l}\text { Means } \\
\text { square }\end{array}$ & F & Decision \\
\hline Between groups & .624 & 2 & .312 & .168 & $\begin{array}{l}\text { Not } \\
\text { Significant }\end{array}$ \\
Within groups & 216.576 & 177 & 1.851 & & \\
Total & 217.200 & 119 & & & \\
\hline
\end{tabular}

Hypothesis 3: There is no significant difference in users'self-perception, other Accents users' perception and users' metaperception of the intelligibility of Accent3.

Table 6. ANOVA result of each users' self-perception, other accents users' perception and users' metaperception of the intelligibility of Accent3

\begin{tabular}{|l|l|l|l|l|l|l|}
\hline & $\begin{array}{l}\text { Sum of } \\
\text { square }\end{array}$ & df & $\begin{array}{l}\text { Mean } \\
\text { square }\end{array}$ & F & Sig & Decision \\
\hline Between groups & .624 & 2 & 19.74 & 5.8 & $\begin{array}{l}.00 \\
4\end{array}$ & $\begin{array}{l}\text { Significan } \\
\mathrm{t}\end{array}$ \\
Within groups & 397.64 & $\begin{array}{l}17 \\
7\end{array}$ & 3.40 & & & \\
Total & 437.13 & & 119 & & & \\
\hline
\end{tabular}


International Journal of Applied Linguistics \& English Literature

ISSN 2200-3592 (Print), ISSN 2200-3452 (Online)

Vol. 1 No. 5; September 2012 [Special Issue on General Linguistics]

Duncan post hoc Test Result.

\begin{tabular}{|l|l|l|l|}
\hline Intelligibility of Accents & \multicolumn{2}{|l|}{$\begin{array}{l}\text { Subset for alpha } \\
=.05\end{array}$} \\
\hline Users'self perception & N & I & \\
Other accent User's perception & 58 & 5.18 & a \\
User's metaperception & 73 & 5.46 & b \\
Significance & 49 & 5.79 & c \\
\hline
\end{tabular}

* Means of the same letter are not significantly different

Hypothesis 4: There is no significant difference in users'self-perception, other Accents users' perception and users' metaperception of the intelligibility of Accent 1.

Table 7. ANOVA result of each user's self-perception, other accents users' perception and users' metaperception of the intelligibility of Accent1.

\begin{tabular}{|l|l|l|l|l|l|l|}
\hline & $\begin{array}{l}\text { Sum of } \\
\text { square }\end{array}$ & Df & $\begin{array}{l}\text { Mean } \\
\text { square }\end{array}$ & F & Sig & $\begin{array}{l}\text { Decision } \\
\text { Significa } \\
\text { nt }\end{array}$ \\
$\begin{array}{l}\text { Between } \\
\text { groups }\end{array}$ & 12.23 & 2 & 6.12 & 2.55 & 0.43 & \\
$\begin{array}{l}\text { Within } \\
\text { groups }\end{array}$ & 280.76 & 177 & 240 & & & \\
Total & 292.99 & 119 & & & & \\
\hline
\end{tabular}

Duncan post hoc Test Result.

\begin{tabular}{|l|l|l|l|}
\hline & & $\begin{array}{l}\text { Subset } \\
\text { for alpha } \\
=.05\end{array}$ & \\
\hline $\begin{array}{l}\text { Acceptability of accent } \\
1\end{array}$ & $\mathrm{~N}$ & $\mathrm{I}$ & \\
$\begin{array}{l}\text { Users' self perception } \\
\text { Other accent user' }\end{array}$ & 53 & 4.90 & $\mathrm{~b}$ \\
$\begin{array}{l}\text { Perception. } \\
\text { Users' metaperception } \\
\text { Sig }\end{array}$ & 49 & 5.18 & $\mathrm{a}$ \\
\hline
\end{tabular}

* Means of the same letter are not significantly different.

Hypothesis 5: There is no significant difference in users'self-perception, other Accents users' perception and users' metaperception of the intelligibility of Accent2. 
International Journal of Applied Linguistics \& English Literature

ISSN 2200-3592 (Print), ISSN 2200-3452 (Online)

Vol. 1 No. 5; September 2012 [Special Issue on General Linguistics]

Table 8. ANOVA result of each user's self-perception, other accents users' perception, users' metaperception of the intelligibility of Accent2.

\begin{tabular}{|l|l|l|l|l|l|l|}
\hline & $\begin{array}{l}\text { Sum of } \\
\text { square }\end{array}$ & df & $\begin{array}{l}\text { Mean } \\
\text { squar } \\
\text { e }\end{array}$ & F & Sig & Decision \\
\hline Between groups & 20.22 & 2 & 10.11 & 4.36 & .015 & Significant \\
Within groups & 397.64 & 17 & 3.40 & & & \\
Total & 437.13 & 7 & 119 & & & \\
\hline
\end{tabular}

Duncan post hoc Test Result.

\begin{tabular}{|l|l|l|l|}
\hline & & $\begin{array}{l}\text { Subset for } \\
\text { alpha }=.05\end{array}$ & \\
\hline Acceptability of accent 1 & N & I & \\
Users' self perception & 58 & 5.2105 & a \\
Other accent user' & 49 & 5.3824 & b \\
Perception. & & & \\
Users' metaperception & 73 & .055 & $\mathrm{c}$ \\
Sig & & & \\
\hline
\end{tabular}

Hypothesis 6: There is no significant difference in users'self-perception, other accents users' perception and users' metaperception of the intelligibility of Accent3.

Table 9. ANOVA result of each users' self-perception, other accents users' perception, users' metaperception of the intelligibility of Accent3

\begin{tabular}{|l|l|l|l|l|l|l|}
\hline & $\begin{array}{l}\text { Sum of } \\
\text { square }\end{array}$ & Df & $\begin{array}{l}\text { Mean } \\
\text { square }\end{array}$ & F & Sig & Decision \\
\hline $\begin{array}{l}\text { Between } \\
\text { groups } \\
\begin{array}{l}\text { Within } \\
\text { groups } \\
\text { Total }\end{array}\end{array}$ & 8.88 & 2 & 4.44 & 1.6 & .003 & Significant \\
\hline
\end{tabular}

Duncan post hoc Test Result.

\begin{tabular}{|l|l|l|l|}
\hline & & $\begin{array}{l}\text { Subset for } \\
\text { alpha }=.05\end{array}$ & \\
\hline Acceptability of accent 1 & $\mathrm{N}$ & $\mathrm{I}$ & \\
Users' self perception & 73 & 5.21 & $\mathrm{a}$ \\
$\begin{array}{l}\text { Other accent user' } \\
\text { Perception. }\end{array}$ & 58 & 5.29 & $\mathrm{a}$ \\
Users' metaperception & 49 & 5.35 & $\mathrm{~b}$ \\
Sig & & .66 & \\
\hline
\end{tabular}

* Means of the same letter are not significantly different 
International Journal of Applied Linguistics \& English Literature

ISSN 2200-3592 (Print), ISSN 2200-3452 (Online)

Vol. 1 No. 5; September 2012 [Special Issue on General Linguistics]

\subsection{Summary of Findings}

The following is a summary of major findings.

\begin{tabular}{|l|l|l|l|}
\hline S/N & INDEX OF MEASURE & MOST INTELLIGIBLE & LEAST INTELLIGIBLE \\
\hline 1 & Users' Self-perception of accents & Accent 3 (MTBNEA) & Accent 2 (RNEA) \\
\hline 2 & Other User's Perception of accents & Accent 1 (ENEA) & Accent2 9RNEA0 \\
\hline 3 & User's Metaperception of accents & Accent 1 (ENEA) & Accent 3 (MTBNEA) \\
\hline & & MOST ACCEPTABLE & LEAST ACCEPTABLE \\
\hline 1 & Users' Self-perception of accents & Accent 1 (ENEA) & Accent 3 (MTBNEA) \\
\hline 2 & Other Use's Perception of accents & Accent 1 (ENEA) & Accent 2 (RNEA) \\
\hline 3 & User's Metaperception of accents & Accent 1 (ENEA) & Accent 3 MTBNEA) \\
\hline
\end{tabular}

There was no significant difference in users' self-perception, other accents users' perception, and users' metaperception of the intelligibility of Accent 1. Based on the results, two of the perceptual forms (other accent users' perception and user's metaperception) showed that Accent 1 was the most acceptable, while all three perceptual forms indicated that Accent 1 was the most intelligible.

\subsubsection{Conclusions and Recommendations}

The following conclusions and recommendations are based on the summary of finding with close reference to research questions and hypotheses already stated.

\subsubsection{Conclusions}

Based on the results and findings, the following conclusions can be reached.

Educated NE accent was the most intelligible and acceptable, followed by the MTbNE accent and the RNE Accent. The least intelligible and acceptable accent was the Regional NE accent. This presents an interesting angle: could it be that NE users favour narrow linguistic ethnicism over broad linguistic regionalism and what are the reasons for this?

There was no significant difference on the intelligibility of the Regional NE accent among the three perceptual forms. There is a near perfect convergence on accent 2 (regional NE accent) as the least intelligible. There was also significant difference on the acceptability of each of the three NE accents. In addition, the degree of perceptual convergence for both intelligibility and acceptability among the three perceptual forms learned towards the Educated NE accent making it the most generally intelligible and acceptable among Nigerian users of the English language. Again, this might be because the Educated NE is closest to Standard British English.

\subsubsection{Recommendations}

Based on the findings, it is recommended that language policy makers realistically confront the problem of the NE corpus to be used in teaching and other educational purposes. The Nigerian Educational Research and Development Council and other allied bodies could be commissioned to produce texts on the phonology and phonetics of the educated NE accent found to be most intelligible and acceptable. This would help the process of standardization and codification.

In addition, textbook writers should take note of codified variations and write textbooks based on ENE which is closest to Sandard English for the use in educational institutions. Teacher educators should be trained in the rudiments of the Educated NE accent. This would enable students learn the correct and acceptable NE accent. 
International Journal of Applied Linguistics \& English Literature

ISSN 2200-3592 (Print), ISSN 2200-3452 (Online)

Vol. 1 No. 5; September 2012 [Special Issue on General Linguistics]

\section{References}

Awonusi, V.O (2004). The English language in global context. In A.B.K Dadzie, and S. Awonusi. (eds).

Nigerian English, influences and characteristics. Pp. 33-45. Lagos: Concept Pub.

Adetugbo, Abiodun. (1987). Nigerian English phonology: Is there any standard? Lagos Review of English Studies IX, $64-84$.

Adetugbo, Abiodun. (1987). Nigerian English and Communicative Competence. In E. Ubahakwe (ed) Varieties and Functions of English in Nigeria. pp. 167-183. Ibadan: African University Press.

Babatunde, Shola T. (2002a). World Englishes and the Paradox of English Language Teaching in Nigeria. In S.T. Babatunde and D.S. Adeyanju (eds) Language, Meaning and society in honour of E.E. Adegbija at 50. pp. 69-95. Ilorin: Haytee press.

Babatunde, Shola T. (2002b). The State of English language in Nigeria. In R.A. Lawal, I. Isiugo Abanihe, 1.N.Ohia (eds) Perspectives in Applied Linguistics in Language and Literature. pp. 129-140.Ibadan: Stirling Horden.

Bamgbose, Ayo. (1995). English in the Nigerian Environment. In A. Bamgbose, A. Banjo, A. Thomas (eds) New Englishes: A West African perspective. pp. 9-26. Ibadan: Mosoro.

Banjo, Ayo. (1979). Beyond Intelligibility: A presidential address. In E. Ubahakwe, E (ed) Varieties and Functions of English in Nigeria. pp. 7-13. Ibadan: African University press.

Banjo, Ayo. (1995). On Codifying Nigerian English: Research So Far. In A. Bamgbose, A. Banjo, A. Thomas (eds) New Englishes: AWest African Perspective. pp. 203-231.Ibadan: Mosoro.

Brosnahan, Leonard F. (1958). English in Southern Nigeria. English Studies 39 (3), pp. 97-110.

Crystal, D. (2007). English as a Global Language. Cambridge: Cambridge University Press.

Ekong, P.A. (1980). Investigating into the Intelligibility of a Possible Standard Model for Nigerian Spoken English. In S.O. Umoh. (ed) Jounal of language Arts and Communication. 1(1), pp. 1 - 11.

Federal Republic of Nigeria (2004, revised 2007). National Policy on Education. Lagos: NERDC Press.

Jowitt, David. (1991). Nigeria English Usage: an introduction. Lagos: Longman.

Jibril, Munzali. (1986). Sociolinguistic Variation in Nigerian English. English Worldwide 7, pp. 47-75.

Kachru, Braj. (1992).World Englishes: Approaches, issues and resources: Language Teaching 25 (1). Cambridge University Press. pp.1-14.

Kachru, B.B., Kachru, Y. and Nelson, C. (2009). The Handbook of World Englishes. Wiley-Blackwell

Lawal, Adebayo. (2000). Perceptual Convergence as a measure of Acceptability and Intelligibility of Nigerian Englishes. Unpublished paper, Faculty of Education, University of Ilorin.

Odumuh, Adama. (1984). Some Methodological Considerations in the Identification and Description of Nigerian English. In R. Freeman \& M. Jubril (eds). Papers of Nigerian English Studies Association / British Council Conference, Bayero University Kano, 25 - 31.

Odumuh, Adama. (1987). Nigerian English: Selected essays. Pp. iv, 67.Zaria: Ahmadu Bello University Press.

Ohia Isaac N. (1997). The Lexicon of Standard Nigerian English As An Acceptability Paradigm Among the Educated Elite. An Unpublished Ph. D. Thesis. University of Ibadan.

Soyinka, Wole. (1993). Art, Dialogue and Outrage. Ibadan: New Horn Press.

Tiffen, Brian. (1974). The Intelligibility of Nigerian English. Unpublished Ph.D.Thesis. University of London, London.

Ubahakwe, Ebo. (1979) (ed). Varieties and Functions of English in Nigeria. Ibadan: Ibadan University Press. 
International Journal of Applied Linguistics \& English Literature

ISSN 2200-3592 (Print), ISSN 2200-3452 (Online)

Vol. 1 No. 5; September 2012 [Special Issue on General Linguistics]

APPENDIX I

UNIVERSITY OF ILORIN

DEPARTMENT OF ART AND SOCIAL SCIENCES EDUCATION

INTELLIGIBILITY AND ACCEPTABILITY RATING SCALE.

(QUESTIONNAIRE)

\section{Dear Respondent,}

This questionnaire is designed to obtain valid information on which of the three accents of Nigerian English will be most intelligible and acceptance to users. I wish to assure you that all information supplied is for academic purposes and would have significant effect on the outcome of this study.

Thanks

Yours faithfully,

F.F. O. Fatimayin (Mrs.)

INSTRUCTION: Please indicate your response by putting a tick $(\checkmark)$ in the appropriate space provided.

\section{PART A: PERSONAL / DEMOGRAPHIC INFORMATION.}

I. State of Origin.

II. Place of work.

III. Status / Rank / Designation.

IV. Sex: Male ( ) Female ( )

V. Age Range :
a. below 30
b. $30-40$
c. $41-50$
d. above 50

VI. What is your mother tongue?

VII. Which region does your mother tongue belong?
(a) North
(b) East
(c) West

VIII. What other Nigerian language(s) are you proficient in?

a

b

c

IX. What is your level of Education?

a Tertiary (Higher degree)

b Tertiary (First degree)

c Tertiary (NCE, diploma)

d Secondary

e Primary 
International Journal of Applied Linguistics \& English Literature

ISSN 2200-3592 (Print), ISSN 2200-3452 (Online)

Vol. 1 No. 5; September 2012 [Special Issue on General Linguistics]

$\mathrm{X}$ Occupation. Please tick the most specific.

a. Lecturer / Teacher

b. Professional (doctor, lawyer, clergyman)

c. Professional writer

d. Journalist ( newspapers / magazine)

e. Broadcaster (radio / TV)

f. Politician

g. Civil servant

h. Others ( Specify)

\section{PART B}

\section{Dear Respondent,}

Please listen attentively to the recorded accents (three of them) that would be played to your hearing. Then answer the questions below by ticking $(\checkmark)$

1. Rate each accent on the basis of its intelligibility (i.e. how easily you can understand the message of the speaker).

\begin{tabular}{|c|c|c|c|c|c|}
\hline ACCENT & 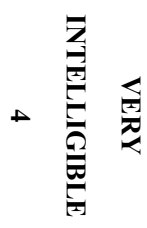 & 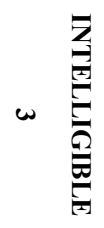 & 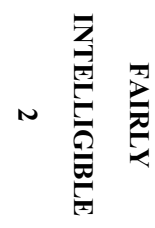 & 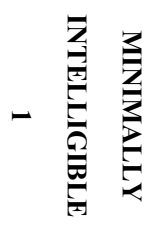 & 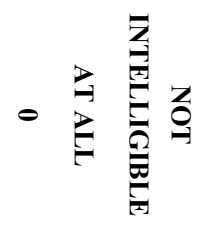 \\
\hline \multicolumn{6}{|l|}{1} \\
\hline \multicolumn{6}{|l|}{2} \\
\hline 3 & & & & & \\
\hline
\end{tabular}

2. Rate each accent on the basis of its acceptability (i.e. the extent to which you like or prefer the accent).

\begin{tabular}{|c|c|c|c|c|c|}
\hline ACCENT & 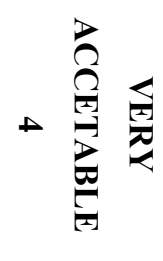 & 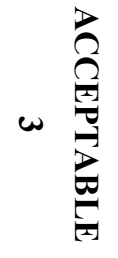 & 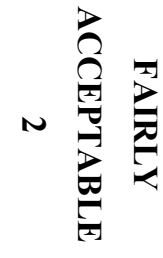 & 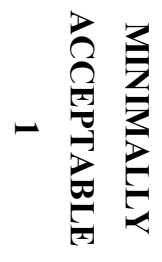 & 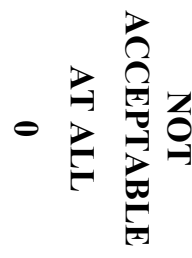 \\
\hline \multicolumn{6}{|l|}{1} \\
\hline 2 & & & & & \\
\hline 3 & & & & & \\
\hline
\end{tabular}

3. Rate each accent on the basis of how easily understandable the accent is.

\begin{tabular}{|c|c|c|c|c|c|}
\hline ACCENT & 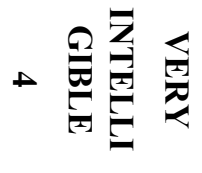 & w & 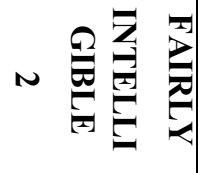 & 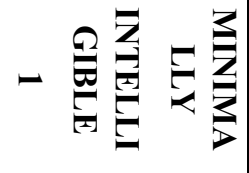 & 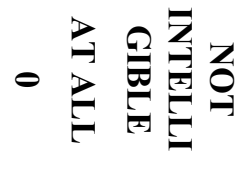 \\
\hline 1 & & & & & \\
\hline 2 & & & & & \\
\hline 3 & & & & & \\
\hline
\end{tabular}


International Journal of Applied Linguistics \& English Literature

ISSN 2200-3592 (Print), ISSN 2200-3452 (Online)

Vol. 1 No. 5; September 2012 [Special Issue on General Linguistics]

4.Rate each accent on the basis of how easily acceptable the accent is (i.e. how readily you feel they will accept it).

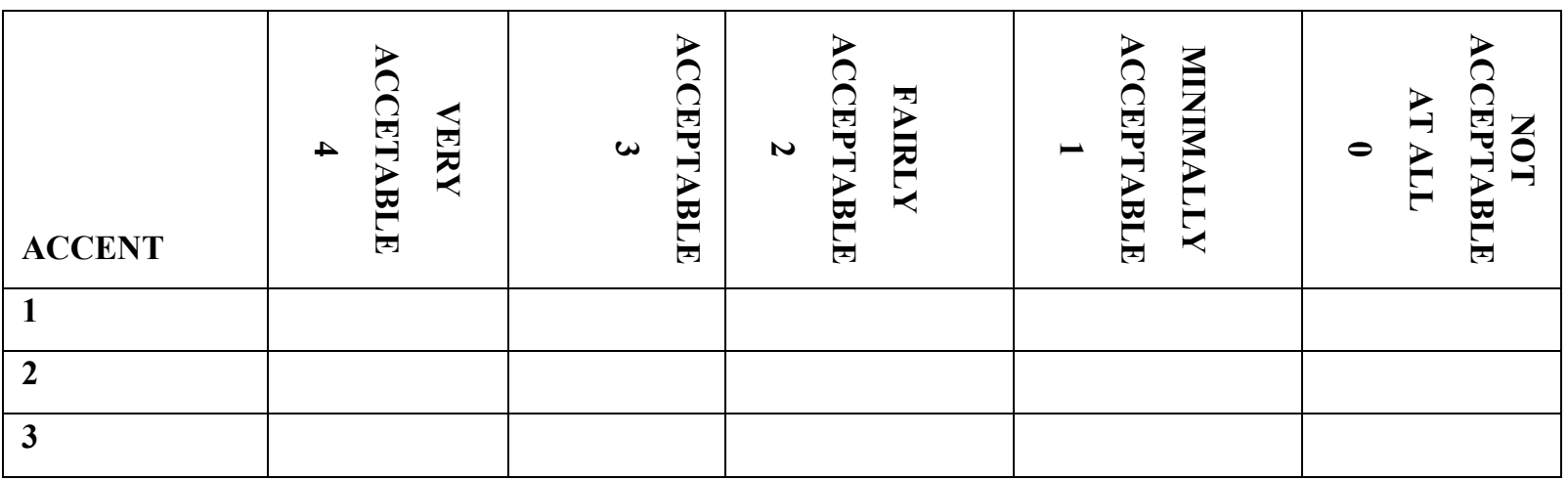

5a. Which of the accent do you prefer most?
Accent A (
) Accent B (
) Accent $\mathrm{C}(\quad)$

$5 \mathrm{~b}$ Why?

6a Which of the accents do you most easily understand?
Accent A (
) Accent B (
) Accent C (

6b. Why?

7. How would you rate your accent of English?

\begin{tabular}{|l|l|l|l|c|}
\hline Very Intelligible & Intelligible & Fairly Intelligible & $\begin{array}{c}\text { Minimally } \\
\text { Intelligible }\end{array}$ & $\begin{array}{c}\text { Not Intelligible at } \\
\text { all }\end{array}$ \\
\hline & & & & \\
\hline
\end{tabular}

8. How do you feel other accent users rate your accent of English?

\begin{tabular}{|c|c|c|c|c|}
\hline Very Intelligible & Intelligible & Fairly Intelligible & $\begin{array}{c}\text { Minimally } \\
\text { Intelligible }\end{array}$ & $\begin{array}{c}\text { Not Intelligible at } \\
\text { all }\end{array}$ \\
\hline & & & & \\
\hline
\end{tabular}

9. How acceptable do you think your accent is?

\begin{tabular}{|c|c|c|c|c|}
\hline Very Intelligible & Intelligible & Fairly Intelligible & $\begin{array}{c}\text { Minimally } \\
\text { Intelligible }\end{array}$ & $\begin{array}{c}\text { Not Intelligible at } \\
\text { all }\end{array}$ \\
\hline & & & & \\
\hline
\end{tabular}

10. How acceptable do you think your accent is to other Nigerian users of English?

\begin{tabular}{|l|l|l|l|c|}
\hline Very Intelligible & Intelligible & Fairly Intelligible & $\begin{array}{c}\text { Minimally } \\
\text { Intelligible }\end{array}$ & $\begin{array}{c}\text { Not Intelligible at } \\
\text { all }\end{array}$ \\
\hline & & & & \\
\hline
\end{tabular}

\section{APPENDIX II}

\section{Section A}

Jimoh:

Agric Officer:

Jimoh:

Agric Officer:

Jimoh:

\section{ORAL READING TESTS FOR ACCENT IDENTIFICATION}

Welcome to my farm, Madam.

Good morning, it's a pleasure to be here. How is the planting going?

Madam, we've been waiting for you.

You've been waiting for me? It's only half past seven.

That's true but we've been careful not to plant without your instruction. 
International Journal of Applied Linguistics \& English Literature

ISSN 2200-3592 (Print), ISSN 2200-3452 (Online)

Vol. 1 No. 5; September 2012 [Special Issue on General Linguistics]

Agric Officer:

Jimoh:

Agric Officer:

Jimoh:

Agric Officer:

\section{Section B}

On her wedding day, the groom's people announced their coming only with the aggressive blare of car horns. We were not very impressed by the show. Although we could not see over the hedge, we could tell from the sound that it was a small procession of eight cars. In addition, there was neither video coverage nor cameraman to air it on television. At the end of it all, the occasion was below standard and not pleasurable and one of the worst I have witnessed.

\section{Section C \{SENTENCES}

a. $\quad$ Attention please! Passengers for flight 557 should assemble at gate 3 .

b. At the end of the story, they all shouted with joy.

c. The headmaster ordered the boy to go home for six days.

d. $\quad$ They are as thick as thieves.

e. They could find only a kite near the cushion chair on which the judge sat.

f. Watching church programmes on television gives me great pleasure and comfort.

g. The seats in the zinc structure are for sitting on.

h. He must endure your fury.

i. There were lots of red lorries, yellow lorries, lilac lorries being loaded on the road with tubers of yams.

j. The nation is taking measures to provide plenty of permanent jobs for her graduates as well as make them computer literate.

k. The man wearing a purplish pint cape appeared twice on television.

\section{Section D INTONATION}

I am going home

What is your name?

Prices have fallen sharply.

Are you going home?

I don't like long journeys, do you?

Will Busayo accept the gift?

James isn't too young to enter University, but Angela is.

You may be right.

Would you rather take beans or rice?

When the truth is known my stand would be clear.

Section E STRESS (DI \& POLY SYLLABUS)

The car behind stopped at the corner.

A man of words and not of deeds

Take the beggar away to the foreman

He likes to work everyday

I have just signed a contract with the Record company.

$\begin{array}{ll}\text { Di syllabic } & \text { Poly-syllabic } \\ \text { window } & \text { personification } \\ \text { Annoy } & \text { aristocracy } \\ \text { Behind } & \text { photographic } \\ \text { Alone } & \text { separate } \\ \text { Machine } & \text { objectivity }\end{array}$


西每

International Journal of Applied Linguistics \& English Literature

ISSN 2200-3592 (Print), ISSN 2200-3452 (Online)

Vol. 1 No. 5; September 2012 [Special Issue on General Linguistics]

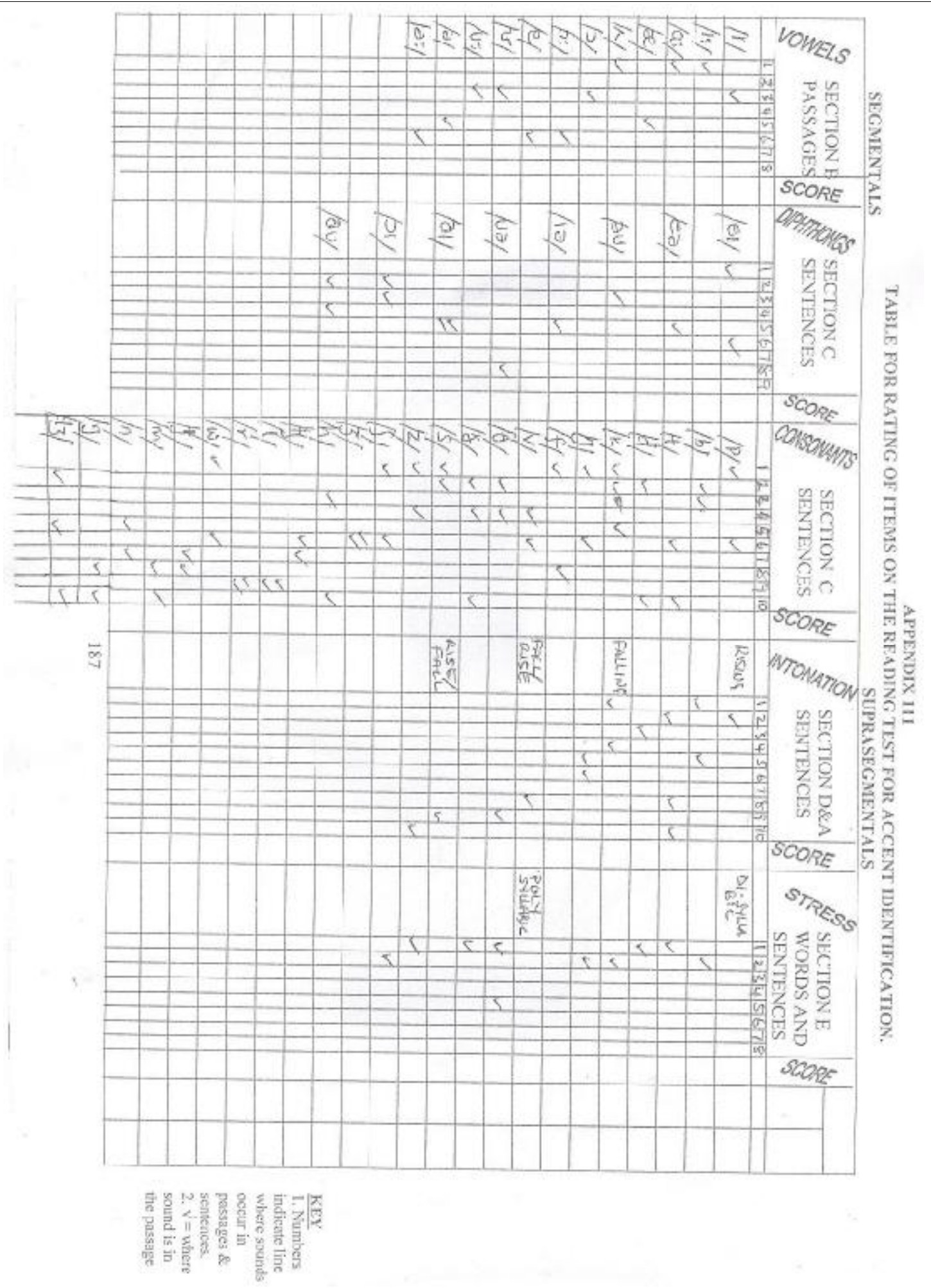

